Ekonomia - Wroclaw Economic Review 24/4 (2018)

Acta Universitatis Wratislaviensis

No 3882

DOI: 10.19195/2084-4093.24.4.6

Anna Cuda

ORCID: 0000-0002-7848-8101

Uniwersytet Wrocławski

anna.cuda@uwr.edu.pl

\title{
Nowe technologie w systemie ochrony zdrowia na przykładzie Stanów Zjednoczonych i Polski
}

Artykuł nadesłany: 7 grudnia 2018 r.; artykuł zaakceptowany: 10 grudnia 2018 r.

JEL Classification: I18, M20, O35, O38

Keywords: digitization, digital transformation, innovation, healthcare industry, healthcare system

\begin{abstract}
New technologies in healthcare systems based on the examples of the US and Poland

The main purpose of this paper is to present the level of new technologies implementation in the healthcare systems in US and Poland. New technologies play a crucial role in everyday life, including healthcare. Medical documentation and easy access to potentially life-changing or lifesaving information are extremely important for all the stakeholders in the healthcare system - its preparation, archiving and effective use in real time upon request may be supported by advanced systems. IT systems may improve security, medical services quality and efficiency of medical treatment, regardless of the type of healthcare system - private in the US and public in Poland. The results of surveys conducted by the American Society of Health-System Pharmacists and the Polish Centrum Systemów Informacyjnych Ochrony Zdrowia [Center of Healthcare Information Systems] have been used in this paper.
\end{abstract}

\section{Wstęp}

Postęp technologiczny jest nieodłącznym elementem rozwoju gospodarki oraz ludzkości. Dynamiczny rozwój technologii wiąże się z szybkimi zmianami, które mogą okazać się korzystne, ale jednocześnie mogą tworzyć wiele zagrożeń nie tylko na etapie ich wdrażania. $Z$ założenia rozwój technologii jest procesem ukierunkowanych zmian dążących do udoskonalenia. Obecnie innowacyjne roz- 
wiązania są w błyskawicznym tempie kreowane i implementowane przez przedsiębiorstwa, organizacje czy rządy. Rozwój nauki jest zdecydowanie szybszy niż percepcyjne możliwości ludzkiego umysłu — wymaga ciągłego uczenia się, udoskonalania, przystosowywania do zmian, aby móc świadomie i w pełni wykorzystywać nową wiedzę, której nieustannie przybywa, oraz tworzyć kolejne innowacje. Wykorzystanie nowych technologii w celu integracji danych w zakresie opieki medycznej niesie wiele korzyści związanych nie tylko z samą ewidencją danych, lecz przede wszystkim z efektywnym wykorzystaniem ich w przyszłym procesie leczenia, które ma szansę stać się szybsze i bardziej skuteczne. Celem niniejszego artykułu jest przedstawienie stopnia wdrożenia nowych technologii w zakresie digitalizacji i cyfryzacji dokumentacji medycznej w dwóch zupełnie różnych krajach: w Stanach Zjednoczonych, które mają nowoczesny i jednocześnie największy prywatny system opieki zdrowotnej na świecie, oraz w Polsce, w której system opieki zdrowotnej jest publiczny i znajduje się w fazie wdrażania rewolucyjnych innowacji technologicznych i rozwiązań, mających na celu go usprawnić. Praca została napisana na podstawie studiów literaturowych z zakresu ekonomii, medycyny i zarządzania, z wykorzystaniem badań wtórnych dotyczących analizy systemu opieki zdrowotnej w Stanach Zjednoczonych oraz w Polsce.

\section{Teoretyczny aspekt innowacji w zakresie integracji danych medycznych}

Innowacje technologiczne wprowadzają lepsze lub zupełnie nowe rozwiązania, rewolucjonizując wiele dziedzin nauki — nierzadko tworząc zupełnie nowe dziedziny. Ich ekonomiczny oraz społeczny wymiar przekłada się na poprawę jakości życia człowieka, a tym samym na poziom opieki zdrowotnej. Branża medyczna niewątpliwie odgrywa szczególną rolę w gospodarce światowej — cechuje ją bardzo wysoka innowacyjność, której towarzyszą wielkie oczekiwania społeczne dotyczące zarówno szybkiego wdrażania innowacji z zakresu leczenia oraz uczynienia ich łatwo dostępnych szerokiemu gronu pacjentów, jak i dbania o poprawę ogólnego stanu zdrowia i przedłużania życia ludzkiego. Ze względu na swoją specyfikę branża ta wymaga współpracy sektora naukowego z biznesem w obliczu potrzeb zgłaszanych przez społeczeństwo, do których należy dostęp szeroko rozumianych innowacji w dziedzinie medycyny, takich jak nowoczesna aparatura ułatwiająca diagnostykę, nowatorskie terapie przeciwbólowe, nowe lub ulepszone leki ratujące życie czy sprawny system wymiany informacji ułatwiający szybką i właściwą diagnozę. Należy pamiętać, że innowacjami nie są jedynie produkty lecznicze czy specjalistyczna aparatura - są nimi też rozwiązania systemowe, zwiększające efektywność z punktu widzenia lekarzy oraz pacjentów. Lista potrzeb zgłaszanych przez obydwie wspomniane grupy jest długa - wręcz nieskończona, jednak postęp technologiczny umożliwia sprawne i częściowe ich zaspokajanie. 
Innowacje technologiczne są nieodłączną częścią medycyny — udoskonalają i poniekąd zmieniają jej oblicze. Od wielu lat urządzenia takie jak rozrusznik serca, dializator (tak zwana sztuczna nerka) ratują ludzkie życia. Obecnie na rynku można znaleźć przeróżne elektroniczne gadżety oraz aplikacje mobilne ułatwiające samodzielną kontrolę stanu zdrowia, które śledzą i mierzą wiele aspektów życia codziennego, między innymi kontrolują liczbę przebytych kroków, pokonanych pięter, mierzą puls, umożliwiają ewidencję pomiarów ciała, wyników laboratoryjnych, przebytych chorób wraz z zaleceniami lekarza prowadzącego, czyli tak zwaną dokumentację medyczną, czy spożywanych posiłków w celu oszacowania liczby kalorii, jaka zostaje dostarczona organizmowi. Łatwy dostęp do informacji z zakresu innowacji medycznych oraz szerokiej gamy produktów ułatwiających kontrolę stanu zdrowia przekłada się na wzrost edukacji i świadomości zdrowotnej ludzi oraz potrzebę łatwego dostępu do nowoczesnych produktów i usług.

Wdrażanie innowacji medycznych wymaga ogromnych zasobów - nie tylko finansowych, lecz także ludzkich, w postaci wykwalifikowanych specjalistów, rzeczowych, takich jak nowoczesna aparatura, oraz informacyjnych. Efektywność opieki zdrowotnej można w znaczny sposób poprawić przez gromadzenie, agregację i udostępnianie danych administracyjnych oraz klinicznych. Aby lekarze mogli leczyć w sposób efektywny, potrzebują dostępu do informacji w czasie rzeczywistym, w miejscu świadczenia usługi. $Z$ ekonomicznego punktu widzenia raz wprowadzone dane powinny być dostępne do ponownego wykorzystywania w całym systemie. Jednak takie podejście wymaga współpracy środowiska lekarzy z państwem, dostawcami nowoczesnych rozwiązań informatycznych oraz pacjentami. Prawdziwa i dokładna informacja jest dla lekarza podstawą do postawienia właściwej diagnozy i opracowania planu leczenia [1]. Aby wyeliminować wszelkie błędy i zapewnić swobodny dostęp w czasie rzeczywistym do danych medycznych, konieczna jest digitalizacja oraz cyfryzacja danych w zakresie ochrony zdrowia.

Digitalizacja jest procesem przekształcania danych analogowych w dane cyfrowe i stanowi podstawę cyfryzacji, która polega na rozpowszechnianiu i popularyzowaniu techniki cyfrowej oraz wprowadzaniu na szeroką skalę infrastruktury elektronicznej — jest procesem restrukturyzacji gospodarek, instytucji oraz społeczeństwa na poziomie systemowym. Podczas gdy digitalizacja obejmuje zmiany formatu danych na elektroniczne, cyfryzacja daje nieograniczone możliwości do tworzenia całkowicie nowych produktów i usług w innowacyjnych modelach biznesowych. Dzięki wykorzystaniu technologii cyfrowych możliwe jest zoptymalizowanie wykorzystywanych zasobów w celu sporządzenia dokumentacji medycznej i łańcuchów dostaw, obniżenie kosztów, zwiększenie wydajności i efektywności pracowników, zwiększenie zadowolenia oraz lojalności pacjentów [2]. 
Do sił napędowych procesów cyfryzacji można zaliczyć: wysoką rentowność sektora IT ${ }^{1}$, dynamiczny rozwój rynku oprogramowania, sprzętu oraz usług teleinformatycznych, wysokie i stale rosnące koszty utrzymania tradycyjnych podsystemów informacyjnych [3].

Tworzenie informatycznych systemów umożliwiających gromadzenie, archiwizowanie i przetwarzanie danych jest niezwykle korzystne ze względu na:

— równy i swobodny dostęp do danych — niezależny od liczby użytkowników korzystających z systemu,

— zdalny dostęp do informacji — bez względu na lokalizację użytkowników,

— łatwość tworzenia kopii informacji,

— trwałość danych cyfrowych.

Największym zagrożeniem związanym z procesem cyfryzacji są cyberprzestępstwa - hakowanie, szpiegowanie, kradzież i wyłudzanie danych jest o wiele łatwiejsze w wypadku danych cyfrowych niż analogowych, jej największym zaś kosztem są kwestie związane z kapitałem ludzkim, takie jak wiedza specjalistyczna personelu i szkolenia. Światowa infrastruktura systemów opieki zdrowotnej jest równie wrażliwa i podatna na ataki hakerów jak systemy branży finansowej czy ubezpieczeniowej, przez co wymaga zaawansowanych zabezpieczeń. Do największych wyzwań stojących przed cyfryzacją można zaliczyć: interfejs użytkownika, klasyfikację i indeksowanie, sposób wyszukiwania i prezentacji informacji oraz dostarczania treści, łatwość dostępu. Każde z wymienionych wyzwań jest bezpośrednio związane z ludźmi - użytkownikami danych systemów, których chęć do korzystania $\mathrm{z}$ danego systemu w codziennej pracy i związane z nim zadowolenie stanowią determinanty sukcesu procesu cyfryzacji [4]. Aby wdrożenie nowych rozwiązań było skuteczne, a ich wykorzystanie w codziennej pracy efektywne, należy poświęcić szczególną uwagę personelowi medycznemu, ponieważ to właśnie on w największym stopniu będzie korzystał z nowoczesnego systemu ochrony zdrowia. To czynnik ludzki ma najbardziej decydujący wpływ na to, czy rewolucja w zakresie sporządzania, przechowywania i wykorzystania elektronicznej dokumentacji medycznej się powiedzie.

Implementacja nowoczesnych systemów umożliwiających elektroniczną ewidencję dokumentacji medycznej wymaga wielu zmian w zakresie funkcjonowania podmiotów ochrony zdrowia — nie pod względem technologii, ale przede wszystkim pracowników branży medycznej. Nowe narzędzie może zrewolucjonizować dotychczasową codzienną pracę medyków - czyniąc ją bardziej efektywną i łatwiejszą od strony administracyjnej, jednak bez odpowiedniego przygotowania i szkoleń przekazujących wiedzę na temat nowych systemów może stać się utrapieniem i być źródłem problemów w realizowaniu codziennych obowiązków.

\footnotetext{
${ }^{1}$ IT — ang. information technology - technologie informacyjne.
} 


\section{EHR, czyli elektroniczna karta pacjenta w Stanach Zjednoczonych}

Amerykański sektor opieki zdrowotnej obejmuje pacjentów, wszystkie podmioty świadczące opiekę zdrowotną, firmy ubezpieczeniowe, partnerów zewnętrznych oraz wyznaczone agencje rządowe. Każdy z tych podmiotów wykorzystuje różne systemy, technologie, które często są niekompatybilne. Zróżnicowany ekosystem informatyczny utrudnia, a nawet uniemożliwia interoperacyjność, która jest niezbędna do szybkiej wymiany informacji.

W 2004 roku prezydent Stanów Zjednoczonych George W. Bush przedstawił swój plan dotyczący koncepcji wykorzystania technologii w opiece zdrowotnej, zapewniając, że większość Amerykanów będzie miała EHR ${ }^{2}$ w ciągu najbliższej dekady. W tamtym czasie od 44 tys. do 98 tys. Amerykanów zmarło z powodu błędów medycznych. Wprowadzenie wszystkich papierowych historii chorób Amerykanów do EHR miało umożliwić uniknięcie niebezpiecznych błędów lekarskich, zmniejszyć koszty oraz poprawić jakość opieki zdrowotnej. EHR, czyli elektroniczna karta pacjenta, zawiera takie informacje, jak: notatki medyczne, skierowania, $\mathrm{CDS}^{3}$, wyniki laboratoryjne [5] oraz e-Receptę [6] - ma na celu gromadzenie danych pacjenta i możliwość skutecznej wymiany informacji medycznych w dowolnym momencie, z zachowaniem bezpieczeństwa udostępnionych danych, między autoryzowanymi podmiotami, takim jak laboratoria, szpitale, apteki, gabinety specjalistyczne. Brak takiej interoperacyjności zwiększa ryzyko błędów medycznych oraz zagraża zdrowiu, a tym samym życiu pacjentów, gdyż ratowanie życia wymaga szybkiej interwencji i łatwego dostępu do informacji na temat zdrowia pacjenta. W 2005 roku przeznaczono na ten projekt 100 milionów dolarów, co stanowiło dwukrotność budżetu przyznanego przez prezydenta w 2004 roku [7]. Rządowy portal Healthit.gov przedstawił współczynniki przyjmowania EHR z podziałem na różne typy instytucji opieki zdrowotnej w latach 2008-2015. W latach 2004-2015 ogólna liczba liczba lekarzy korzystających z jakiegokolwiek jakikolwiek EHR ${ }^{4}$ wzrosła ponad czterokrotnie, z 20,8\% do 86,9\% (wykres 1). Odsetek wszystkich szpitali wykorzystujących podstawową wersję EHR $^{5}$ wzrósł prawie dziesięciokrotnie — z 9\% w 2008 roku do 84\% w 2015 roku. W wypadku gabinetów lekarskich wdrożenie podstawowego EHR wzrosło około 3,5 raza w tym samym okresie [8].

${ }^{2}$ EHR - ang. Electronic Healthcare Record - elektroniczny rekord zdrowotny pacjenta w Stanach Zjednoczonych.

${ }^{3}$ CDS - ang. Clinical Decision Support - wsparcie w podejmowaniu decyzji klinicznych.

${ }^{4}$ Jakikolwiek system EHR - system dokumentacji medycznej lub zdrowotnej, który jest całkowicie lub częściowo elektroniczny i nie obejmuje systemów przeznaczonych wyłącznie do fakturowania.

5 Podstawowy EHR - wykorzystuje podstawowe funkcjonalności, takie jak elektroniczne: dane demograficzne pacjentów, listy dolegliwości oraz przyjmowanych leków, uwagi kliniczne, zamówienia na leki, wyniki badań laboratoryjnych oraz obrazowych. 


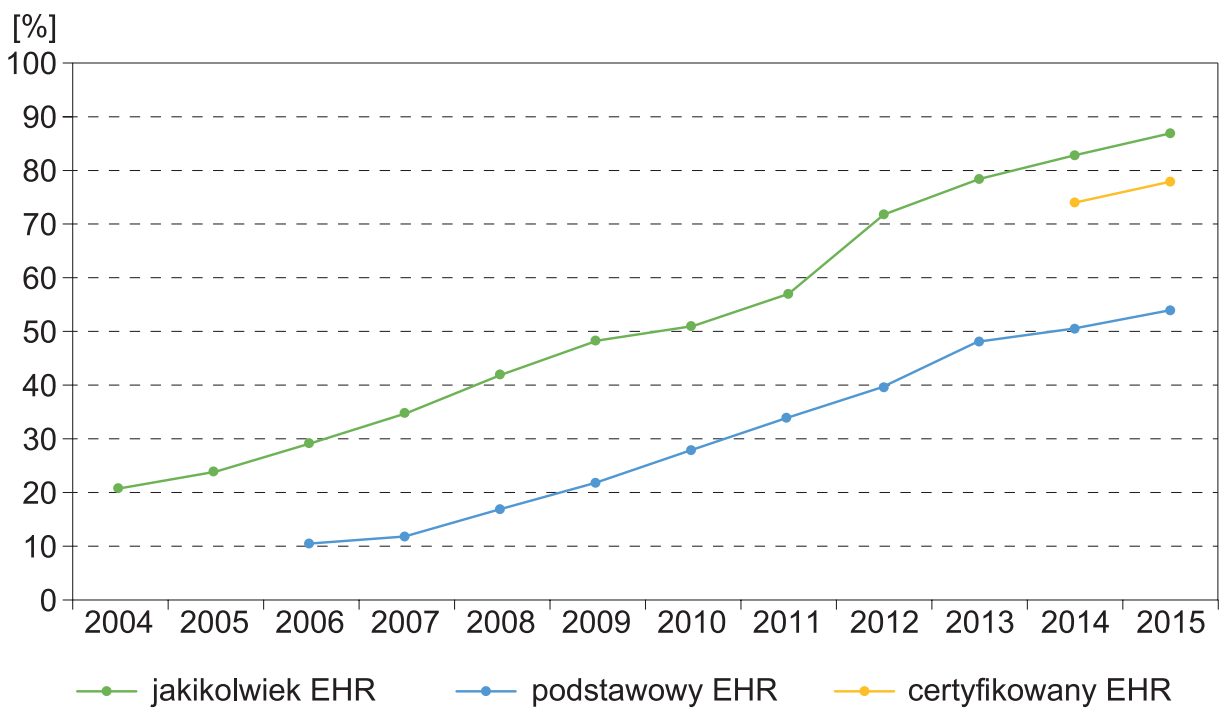

Wykres 1. Odsetek lekarzy korzystających z EHR w Stanach Zjednoczonych w latach 2004-2015

Źródło: opracowanie własne na podstawie Office of the National Coordinator for Health Information Technology. Office-based Physician Electronic Health Record Adoption, Health IT Quick-Stat \#50. dashboard.healthit.gov/quickstats/pages/physician-ehr-adoption-trends.php, December 2016 (dostęp: 1.12.2018).

Według raportu Healthcare Growth Partners rok 2017 był przełomowy w inwestycjach związanych $\mathrm{z}$ nowymi technologiami informacyjnymi $\mathrm{w}$ zakresie opieki zdrowotnej. Od 2011 roku globalne inwestycje wzrosły o 849\%, natomiast inwestycje w nowe technologie związane z opieką zdrowotną wzrosły aż o $583 \%$. W Stanach Zjednoczonych w 2013 roku inwestycje te wyniosły 2,8 mld dolarów, a w 2017 roku osiągnęły poziom 7,1 mld dolarów [9]. System opieki zdrowotnej z założenia ma na celu poprawę zdrowia oraz jakości życia pacjentów, przy jednoczesnym obniżeniu kosztów. Aby móc osiągnąć ten cel, konieczna jest powszechnie dostępna nowoczesna, bezpieczna, wydajna i interoperacyjna infrastruktura informacyjna opieki zdrowotnej.

Przeprowadzane w Stanach Zjednoczonych krajowe badanie American Society of Health-System Pharmacists (ASHP), dotyczące praktyki farmaceutycznej w placówkach szpitalnych, koncentruje się na praktykach oraz technologiach zarządzania i ulepszania systemu opieki ochrony zdrowia. Według analizy danych za rok 2016 aż 99,1\% amerykańskich szpitali korzystało z EHR — co przekłada się na imponujący, ponad trzykrotny, wzrost popularności elektronicznych rekordów zdrowotnych pacjentów w porównaniu do 2003 roku [10]. W 2017 roku spośród amerykańskich szpitali korzystających z inteligentnych pomp infuzyjnych aż 77,4\% było wyposażonych w pompy z funkcją komunikacji bezprzewodowej, która umożliwia zdalną aktualizację bibliotek leków, łączenie się z elektroniczną 
kartą pacjenta (EHR) oraz ciągłe gromadzenie danych jakościowych dotyczących poprawy stanu zdrowia [11]. Tak rewolucyjne rozwiązania technologiczne w sferze ratowania życia ludzkiego podkreślają ogromne znaczenie interoperacyjności i współpracy między prywatnymi dostawcami systemów administracji danych medycznych, bez której wykorzystanie wszystkich możliwości zarówno sprzętu, jak i rozwiązań systemowych nie będzie możliwe.

\section{Nowoczesne usługi medyczne w polskim systemie ochrony zdrowia}

Polski system opieki zdrowotnej jest oparty na modelu ubezpieczeniowym, a Konstytucja Rzeczypospolitej Polskiej stanowi, iż każdy obywatel ma prawo do ochrony zdrowia. Dostęp do świadczeń opieki zdrowotnej jest równy - niezależny od sytuacji materialnej jednostki i finansowany ze środków publicznych. W 2000 roku Rada Europy przyjęła strategię lizbońską, w której został zdefiniowany długofalowy program reform społeczno-gospodarczych wskazujący funkcje technik informacyjno-komunikacyjnych w zakresie rozwoju ochrony zdrowia. Jednostka podległa Ministerstwu Zdrowia w zakresie informatyzacji - Centrum Systemów Informacyjnych Ochrony Zdrowia (CSIOZ) - stworzyła Program Informatyzacji Ochrony Zdrowia złożony z sześciu projektów, które są realizowane etapami. Obecnie realizowane są trzy projekty:

— Projekt P1 — Elektroniczna Platforma Gromadzenia, Analizy i Udostępniania Zasobów Cyfrowych o Zdarzeniach Medycznych,

— Projekt P2 - Platforma Udostępniania Online Przedsiębiorcom Usług i Zasobów Cyfrowych Rejestrów Medycznych,

— Projekt P3 - Platforma Rejestrów Ochrony Zdrowia (PROZ), zakłada stworzenie warunków do wdrożenia usługi e-Zdrowia oraz zwiększenia jakości informacji operacyjnej i strategicznej w ochronie zdrowia; dotyczy systemów związanych z przebudową, dostosowaniem, utrzymywaniem i monitorowaniem rejestrów i innych zasobów ochrony zdrowia przez organy publiczne, w tym administrację państwową i samorządową [12].

E-Zdrowie to zbiór usług elektronicznych w dziedzinie zdrowia, który obejmuje wykorzystanie nowych technologii informacyjnych i komunikacyjnych we wzajemnych relacjach podmiotów rynku ochrony zdrowia: lekarzy, instytucji ochrony zdrowia (takich jak szpitale i przychodnie) oraz pacjentów. Do głównych celów e-Zdrowia należy cyfryzacja rejestrów medycznych z jednoczesnym wzmocnieniem ich podstaw prawnych, interoperacyjność systemów informatycznych, poprawa dostępu administracji publicznej, lekarzy oraz pacjentów do systemów informatycznych, redukcja kosztów gromadzenia oraz przetwarzania danych i wdrożenie dyrektywy UE w sprawie stosowania praw pacjentów w transgranicznej opiece zdrowotnej (dyrektywa 2011/24/UE). Do celów Unii Europejskiej 
w zakresie strategii e-Zdrowie należy poprawa stanu zdrowia obywateli, podniesienie jakości i zwiększenie dostępności usług opieki zdrowotnej oraz udostępnienie i popularyzacja przyjaznych dla użytkowników narzędzi umożliwiających realizację wspomnianych wcześniej dwóch celów [13]. Założona wartość projektu wynosiła prawie $800 \mathrm{mln}$ złotych [14].

Nieprzerwanie trwają prace nad unowocześnieniem polskiego systemu ochrony zdrowia i wdrożenia platformy e-Zdrowie. Tak naprawdę rewolucja już się rozpoczęła — od 1 stycznia 2016 roku polscy lekarze mieli możliwość wystawiania elektronicznych zwolnień lekarskich (e-Zwolnień), a wraz z końcem listopada 2018 możliwość ta zamieniła się w obowiązek — papierowe zwolnienia lekarskie zostały całkowicie zastąpione elektronicznymi [15]. Czas na podłączenie aptek do systemu e-Recept upłynął wraz z końcem grudnia 2018 roku [16].

Z III edycji badań stopnia informatyzacji podmiotów wykonujących działalność leczniczą, przeprowadzonych przed CSIOZ w 2018 roku, wynika, że w porównaniu do 2016 roku liczba podmiotów, które dysponują nowoczesnymi rozwiązaniami technologicznymi do prowadzenia elektronicznej dokumentacji medycznej, wzrosła o ponad $21 \%$. Natomiast procent podmiotów mających strategię związaną z informatyzacją placówki w perspektywie najbliższych lat utrzymuje się na mniej więcej na stałym poziomie. Ponad $91 \%$ szpitali oraz znaczna część placówek świadczących stacjonarne i całodobowe usługi zdrowotne (innych niż szpitale) $-65 \%$ - ma własną serwerownię. Badanie to wykazało, że w ciągu dwóch lat nastąpił wyraźny wzrost działań związanych z przygotowaniem do tworzenia, przechowywania i przetwarzania elektronicznej dokumentacji medycznej, niestety to dopiero początek rewolucji systemu ochrony zdrowia [17].

\section{Wnioski}

Nowe technologie niewątpliwie mają ogromne znaczenie dla jakości opieki zdrowotnej - odgrywają one bowiem główną rolę w przeprojektowaniu całego systemu opieki zdrowotnej i uczynieniu go sprawniej funkcjonującym, bardziej efektywnym, skuteczniejszym. Elektroniczny system danych zdrowotnych jest naturalną i nieuniknioną konsekwencją rozwoju nowych technologii. Wyraźnie skraca czas potrzebny na wprowadzanie danych oraz uzyskanie i analizę informacji koniecznych do zaplanowania leczenia, takich jak dotychczasowe wyniki badań laboratoryjnych, historia przebytych chorób, nietolerancje, uczulenia. Nakłady na inwestycje związane z nowymi technologiami w zakresie opieki zdrowotnej w samym 2017 roku były ponad 33 razy większe w Stanach Zjednoczonych (7,1 mld dolarów) niż wydatki na wdrożenie polskiej platformy e-Zdrowie zaplanowane na realizację całego, wieloletniego projektu $(0,8$ mld złotych, czyli nieco ponad 0,2 mld dolarów). Stany Zjednoczone są o wiele większym państwem nie tylko terytorialnie, lecz także co do liczby ludności — jednak liczba obywateli 
jest zaledwie osiem razy większa. Nakłady na inwestycje związane z technologiami informacyjnymi w sektorze opieki zdrowotnej powinny być wysokie i jednocześnie dobrze rozdysponowane. Systemy powinny być nie tylko interoperacyjne, lecz przede wszystkim przyjazne dla użytkowników — dzięki temu możliwe będzie łatwe gromadzenie, przechowywanie i wykorzystywanie danych w czasie rzeczywistym przez wszystkie upoważnione podmioty sektora ochrony zdrowia. Niezależnie czy sektor ten jest publiczny, czy prywatny, implikacja systemów informacyjnych w zakresie opieki zdrowotnej wymaga ich interoperacyjności oraz wiąże się z jednakowymi korzyściami.

\section{Bibliografia}

[1] FairWarning. Canada, How Privacy Considerations Drive Patient Decision and Impact Patient Care Outcomes, http:// www.fairwarning.com/Canada/whitepapers/2011-12-WP-CANADAPATIENT-SURVEY.pdf (dostęp: 2.12.2018).

[2] Gabriel M.H., Furukawa M.F., Vaidya V., Emerging and Encouraging Trends in E-prescribing Adoption among Providers and Pharmacies, „American Journal of Managed Care” 2013, https://www.ncbi.nlm.nih.gov/pubmed/24304258 (dostęp: 1.12.2018).

[3] Locatelli P., Restifo N., Gastaldi L., Corso M., Health Care Information Systems: Architectural Models and Governance, Innovative Information Systems Modelling Techniques, https://www. intechopen.com/books/innovative-information-systems-modelling-techniques/health-care-information-systems-architectural-models-and-governance (dostęp: 2.12.2018).

[4] Nowak P., Rewolucja cyfrowa w komunikacji naukowej — szanse i zagrożenia, https://repozytorium.amu.edu.pl/bitstream/10593/4717/1/08-Nowak.pdf (dostęp: 3.12.2018).

[5] Gellerstedt M., The digitalization of health care paves the way for improved quality of life?, http://www.iiisci.org/journal/CV\$/sci/pdfs/IP018LL16.pdf (dostęp: 3.12.2018).

[6] Porterfield A., Engelbert K., Coustasse A., Electronic Prescribing: Improving the Efficiency and Accuracy of Prescribing in the Ambulatory Care Setting, 2014, https://www.ncbi.nlm.nih. gov/pmc/articles/PMC3995494/ (dostęp: 1.12.2018).

[7] Wilson K., Khansa L., Migrating to Electronic Health Record Systems: A Comparative Study between the United States and the United Kingdom, „Health Policy” 2018, https://doi. org/10.1016/j.healthpol.2018.08.013 (dostęp: 1.12.2018).

[8] Office of the National Coordinator for Health Information Technology. Office-based Physician Electronic Health Record Adoption, Health IT Quick-Stat, 2016, https://dashboard.healthit. gov/quickstats/pages/physician-ehr-adoption-trends.php (dostęp: 1.12.2018).

[9] Healthcare Growth Partners - US health IT investment skyrockets from $\$ 2.8$ billion to $\$ 7.1$ billion, 26.01.2018, http:/www.hgp.com/research-and-news/2018/01/26/us-health-it-investment-skyrockets-from-\$2.8- billion-to-\$7.1-billion/ (dostęp: 1.12. 2018).

[10] ASHP national survey of pharmacy practice in hospital settings: Prescribing and transcribing 2016, https://academic.oup.com/ajhp/article/74/17/1336/5102661 (dostęp: 25.11.2018).

[11] ASHP national survey of pharmacy practice in hospital settings: Dispensing and administration - 2017, https://academic.oup.com/ajhp/article/75/16/1203/5102109 (dostęp: 25.11.2018).

[12] Krajowe Projekty e-Zdrowie, http://www2.mz.gov.pl/wwwmz/index?mr=m17\&ms=795\&ml= $\mathrm{pl} \& \mathrm{mi}=795 \& \mathrm{mx}=0 \& \mathrm{ma}=16749$ (dostęp: 25.11 .2018$)$.

[13] e-Zdrowie, https://www.gov.pl/web/cyfryzacja/strumien-e-zdrowie (dostęp: 25.11.2018).

[14] Gryza P., Projekt P1 i regionalne platformy e-Zdrowia, https://www.gov.pl/documents/31305/ 188811/projekt_p1_i_regionalne_platformy_e-zdrowia_tryb_zgodnosci.pdf/0ae65508-ab187f94-785d-cdc552085453 (dostęp: 25.11.2018).

Ekonomia - Wroclaw Economic Review 24/4 (2018)

(C) for this edition by CNS 
[15] Elektroniczne zwolnienia lekarskie, http://www.zus.pl/ezla (dostęp: 29.11.2018).

[16] Czas na podtaczenie aptek do e-Recepty, https://www.csioz.gov.pl (dostęp 29.11.2018).

[17] CSIOZ, Badanie stopnia informayzacji podmiotów wykonujących działalność leczniczą, III edycja, czerwiec 2018, https://csioz.gov.pl/fileadmin/user_upload/Biuletyny_informacyjny/badanie_ankietowe_nt_poziomu_informatyzacji_2018_5bbcd177bc7dd.pdf(dostęp: 29.11.2018). 